\title{
PREPARASI IKAN KUNIRAN (Upeneus sulphureus) PADA PROSES PEMISAHAN DAGING MENGGUNAKAN MEAT BONE SEPARATOR
}

\section{Preparations of Kuniran Fish (Upeneus sulphureus) on Its Meat Separation Process using Meat Bone Separator}

\author{
Bakti Berlyanto Sedayu ${ }^{1 *}$, I Made Susi Erawan ${ }^{1}$, dan Putri Wullandari ${ }^{1}$ \\ ${ }^{1}$ Loka Penelitian dan Pengembangan Mekanisasi Pengolahan Hasil Perikanan, \\ JI. Imogiri Barat Km11,5. Bantul - DI.Yogyakarta, Indonesia \\ *Korespondensi Penulis: bakti@kkp.go.id, baktibsedayu@gmail.com
}

Diterima: 12 April 2015; Disetujui: 11 Juni 2015

\begin{abstract}
ABSTRAK
Untuk mendapatkan cara pemisahan daging ikan yang efektif menggunakan meat bone separator, dilakukan preparasi terhadap ikan sebelum dimasukan ke dalam mesin, yaitu: utuh, disayat, dan dibelah. Selain itu, dilakukan juga simulasi pengepresan terhadap ikan menggunakan Texture Analyzer, meniru proses pemisahan daging ikan di antara sabuk penekan dan permukaan silinder berpori pada mesin. Hasil uji menunjukkan bahwa kekerasan ikan dipengaruhi oleh jenis preparasi, dengan nilai tertinggi ikan utuh, kemudian diikuti dengan ikan yang disayat dan dibelah. Jenis preparasi dan kekerasan ikan juga turut mempengaruhi lamanya waktu proses pemisahan, rendemen, serta kualitas daging lumat yang dihasilkan. Hasil percobaan menunjukkan bahwa secara umum, teknik preparasi terbaik yaitu dengan cara disayat, dengan waktu proses pemisahan tercepat $(11,35 \mathrm{~kg} / \mathrm{jam})$, jumlah rendemen yang tinggi $(67,5 \%)$, serta kadar abu yang merepresentasikan kandungan tulang yang terikut dalam daging paling rendah $(0,82 \%$ WB). Selain itu, pada preparasi ikan yang disayat juga memberikan karakteristik fish-gel yang terbaik untuk nilai kekerasan $1.295 \mathrm{~g}$, chewiness 684, dan gumminess 576 .
\end{abstract}

KATA KUNCl: meat bone separator, ikan kuniran, kekerasan, preparasi

\section{ABSTRACT}

To find out an effective process in separating fish meat from its bone and skin using meat bone separator, initial preparations i.e.whole, sliced, and butterflied have been observed. In addition, a simulation of fish compression was tested using Texture Analyzer, to resemble the fish deboning process, which is compressed between the pressure belt and perforated cylinder of the machine. The test demonstrated that the hardness of fish has been affected by preparations. The whole fish gave the highest value of hardness, followed then by sliced and butterflied fish. Moreover, types of preparation and fish hardness also affected to the processing time, yields, and the minced fish quality produced. In general, it was found that the best preparation is the sliced fish resulting in the highest production rate $(11.35 \mathrm{~kg} / \mathrm{h})$, yield of minced fish $(67.5 \%)$, as well as the lowest ash content $(0.82 \%$ WB) representing the remained bone in minced fish. In addition, the sliced fish gave also better physical properties i.e. hardness $1295 \mathrm{~g}$, chewiness 684 and gumminess 576 of the fishgel.

KEYWORDS: meat bone separator, kuniran fish, hardness, preparation

\section{PENDAHULUAN}

Ikan kuniran (Upeneus sulphureus) merupakan salah satu jenis ikan kecil yang memiliki nilai ekonomis rendah. Ikan ini merupakan hasil tangkapan samping yang cukup tinggi kelimpahannya, dan banyak ditemukan di tempat pendaratan ikan di wilayah pesisir utara Jawa. Beberapa kendala dalam proses pengolahan jenis ikan-ikan kecil adalah pemisahan daging ikan dari tulang dan kulitnya. Pemisahan daging ikan tersebut biasa dilakukan secara manual menggunakan pisau atau alat bantu lainnya, tapi cara ini banyak menghabiskan waktu serta tenaga kerja. Selain itu, pemisahan secara manual 
juga dapat menyebabkan menurunnya mutu daging ikan yang dihasilkan dan juga meningkatkan ongkos produksi (Newman, 1981).

Hingga saat ini, pemisahan secara manual masih umum dilakukan oleh pengolah-pengolah di Indonesia, karena masih layak jika dihitung secara ekonomi. Namun demikian, pada saat harga produk olahan ikan harus mampu bersaing di pasaran dengan produk makanan sumber protein lainnya, atau dengan produk perikanan lainnya yang nilainya relatif rendah, maka proses menggunakan mesin menjadi suatu kebutuhan (Mendelsohn \& Callan, 1980). Pemanfaatan daging ikan hasil tangkapan samping biasanya untuk jenis produk olahan berbasis daging lumat (mince-based products) seperti nugget, baso, pempek, dan lainnya yang memiliki nilai tambah yang tinggi, oleh karena itu, mesin pemisah daging ikan (meat bone separator) menjadi sangat penting bagi unit pengolahan.

Prinsip kerja mesin pemisah daging ikan yaitu dengan memaksa daging ikan masuk melalui lubang dengan mengkombinasikan gaya geser dan gaya tekan sehingga posisi ikan terhimpit antara permukaan drum yang berlubang/berpori dan sabuk pengepres. Hal ini memberikan kesempatan daging untuk ekstrusi melalui lubang-lubang tersebut, sehingga tidak hanya tulang, tetapi kulit juga tetap berada di bagian luar drum (Booman et al., 2010).

Sebagai bahan dasar pembuatan produk olahan lanjutan, maka daging lumat yang dihasilkan dari proses pemisahan harus memiliki mutu yang baik. Kualitas daging lumat ikan yang dihasilkan oleh mesin pemisah daging dapat dipengaruhi oleh beberapa faktor, di antaranya material komponen penyusun mesin, kekuatan tekanan pada sabuk pengepres, ukuran diameter pori pada silinder pengepres, kapasitas mesin, dan faktor lainnya (Sedayu et al., 2013). Selain karena jenis atau kemampuan mesin pemisah daging yang digunakan, serta ukuran, ketebalan dan struktur ikan (Purbayanto et al., 2009; Booman et al., 2010), cara preparasi awal terhadap ikan yang akan diproses menggunakan mesin juga diduga mempengaruhi kualitas daging lumat yang dihasilkan. Beberapa parameter daging lumat ikan yang dapat mempengaruhi produk olahan selanjutnya antara lain: warna daging lumat, jumlah tulang yang terikut, tekstur, serta rendemen. Oleh karena itu, pada penelitian ini dilakukan beberapa teknik preparasi awal ikan sebelum diproses menggunakan meat bone separator untuk mendapatkan hasil yang optimal.

\section{BAHAN DAN METODE}

Ikan kuniran segar (Upeneus sulphureus) diperoleh dari Pelabuhan Pelelangan Ikan (PPI) Tegalsari-Tegal, Jawa Tengah. Ukuran rata-rata ikan yaitu: panjang 57,6 $\mathrm{mm}$; lebar 18,1 mm; dan tebal 12,7 mm. Ikan dibawa menggunakan cool box yang diberi es curah untuk mempertahankan suhu dingin selama transportasi. Ikan dipotong kepalanya, dibersihkan isi perutnya, serta dibuang sisiknya, kemudian dilakukan preparasi dengan tiga teknik berbeda sebelum ikan dimasukan/ diproses ke meat bone separator, yaitu : 1) utuh (whole), 2) disayat memanjang (lateral) pada tiap sisinya (sliced), dan 3) dibelah (butterflied) (Gambar 1).

Ikan yang telah dipreparasi diuji kekerasannya menggunakan Stable Micro System TA.XT Plus Texture Analyser (US) pada bagian permukaan lateral line, di sekitar bagian atas abdomen, dengan bagian kulit menghadap ke atas. Masing-masing sampel diuji menggunakan probe $\mathrm{P} 75$, dengan kecepatan pre-test speed $10 \mathrm{~mm} / \mathrm{det}$, dan post-test speed $5 \mathrm{~mm} / \mathrm{det}$.

Selanjutnya, ikan diproses menggunakan meat bone separator rancangan Balai Besar Penelitian dan Pengembangan Pengolahan Produk dan Bioteknologi Kelautan dan Perikanan (Sedayu et al., 2013), yaitu dengan cara dimasukkan ke inlet hopper mulai dari bagian ekor. Sedangkan untuk perlakuan preparasi dibelah, posisi daging ikan yang terbuka menghadap ke silinder berpori (ke atas). Pengamatan yang dilakukan saat proses pemisahan daging ikan meliputi: rendemen dan kecepatan waktu pemisahan daging.

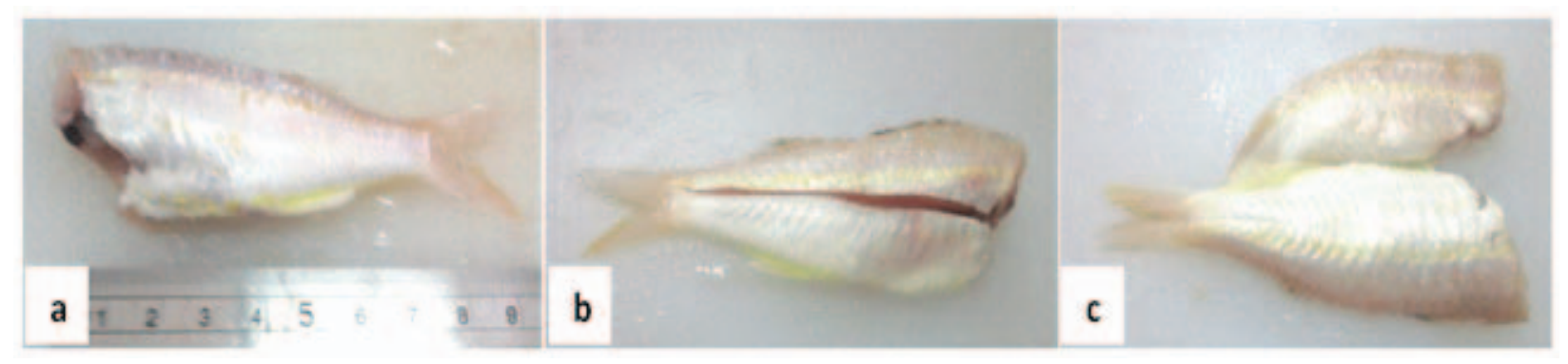

Gambar 1. Perlakuan preparasi ikan kuniran: a)utuh; b)disayat; dan c)dibelah. Figure 1. Fish preparations: a)whole; b)sliced; and c)butterflied. 
Selanjutnya, daging lumat yang dihasilkan diukur mutunya yang meliputi warna, kandungan kimia (proksimat), dan tekstur fish gel yang dihasilkannya.

Warna daging lumat ikan diukur menggunakan Color Flex EZ-Hunter Lab yang meliputi nilai lightness, redness, dan yellowness, sedangkan analisis proksimat meliputi kadar air, kadar abu, kadar protein, dan kadar lemak (AOAC, 2000). Untuk uji tekstur, preparasi daging lumat menjadi kamaboko dilakukan dengan metode Kim dan Park (2000), namun masing-masing sampel diiris dengan ukuran tinggi $3 \mathrm{~cm}$ dan diameter $4 \mathrm{~cm}$, kemudian diuji dengan metode texture profile analysis (TPA) menggunakan Stable Micro System TA.XT Plus Texture Analyser (US). Probe yang digunakan yaitu P75 dengan kompresi sampel (strain) sebesar 30\% selama 5 detik, dengan pengaturan kecepatan penekanan sebesar 5 $\mathrm{mm} / \mathrm{det}$, pre-test speed $10 \mathrm{~mm} / \mathrm{det}$, dan post-test speed $5 \mathrm{~mm} /$ det.

Analisis data statistik pada penelitian ini dilakukan menggunakan PASW Statistic 18-SPSS dan data diolah menggunakan one-way analysis of variance (ANOVA) dengan tingkat signifikan $p=0,05$. Sedangkan untuk melihat perbedaan antar perlakuan dilakukan uji Tukey's post-hoc.

\section{HASIL DAN BAHASAN}

\section{Preparasi Ikan terhadap Sifat Fisik Ikan dan Daging Lumat}

Pada perlakuan simulasi pengepresan menggunakan Texture Analyzer, nilai kekerasan ikan didapatkan saat tekanan yang diberikan menyebabkan deformasi atau kerusakan pada tubuh ikan (Szczesniak et al., 1963). Hasil uji simulasi pengepresan menunjukkan bahwa perlakuan preparasi memberikan pengaruh terhadap nilai kekerasan ikan. Ikan utuh memiliki nilai kekerasan tertinggi, diikuti ikan yang disayat, kemudian ikan yang dibelah (Gambar 2). Hasil uji statistik menunjukkan bahwa ikan utuh memiliki kekerasan yang lebih tinggi secara signifikan dibandingkan kedua perlakuan lainnya $(p<0,05)$, namun kekerasan ikan yang disayat tidak berbeda nyata dengan perlakuan ikan yang dibelah.

Kulit ikan sebagai pelindung tubuh terluar menjadi faktor yang mempengaruhi nilai kekerasan ikan. Terjadinya deformasi saat kompresi menggunakan Textur Analyser didapatkan saat daging ikan pertama kali rusak atau pecah, sehingga perusakan terhadap kulit ikan menyebabkan mudahnya deformasi daging ikan saat diberikan tekanan. Selain itu, ketebalan daging serta kesegaran juga mempengaruhi nilai kekerasan pada ikan kuniran.

Kekerasan ikan yang berbeda dari berbagai preparasi yang dilakukan mempengaruhi lama waktu atau kecepatan proses pemisahan daging menggu akan meat bone separator (Tabel 1). Hal ini disebabkan karena pada saat ikan dimasukan ke dalam bukaan antara sabuk penekan dan silinder berpori lebih sering terjadi "selip", terutama pada perlakuan ikan utuh dibandingkan perlakuan lainnya. Pada praktek pemisahan menggunakan meat bone separator, masih dibutuhkan bantuan dorongan secara manual terhadap ikan agar bisa tergerus masuk di antara sabuk penekan dan silinder berpori (Gambar 3). Selain diakibatkan oleh licinnya permukaan ikan dan sabuk penekan serta silinder berpori yang disebabkan oleh lemak, ketebalan ikan juga mempengaruhi proses pemisahan daging. Semakin tebal ikan yang diproses maka semakin sering terjadi selip, sehingga ikan-ikan yang telah dibelah

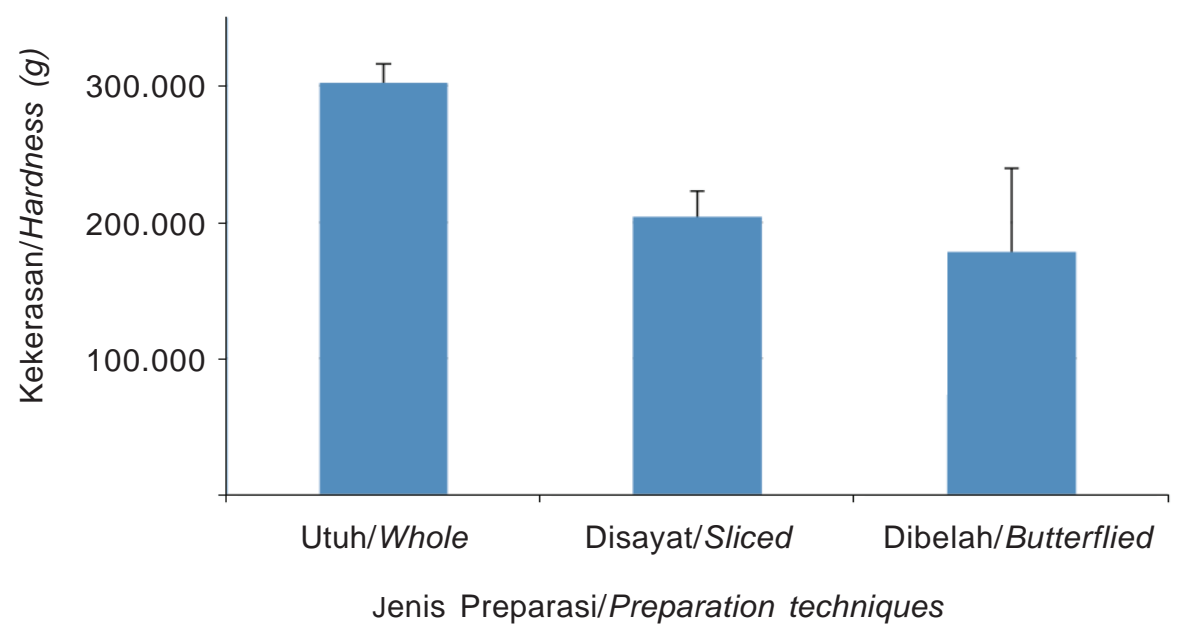

Gambar 2. Jenis preparasi ikan terhadap nilai kekerasannya.

Figure 2. Types of preparation on fish hardness. 


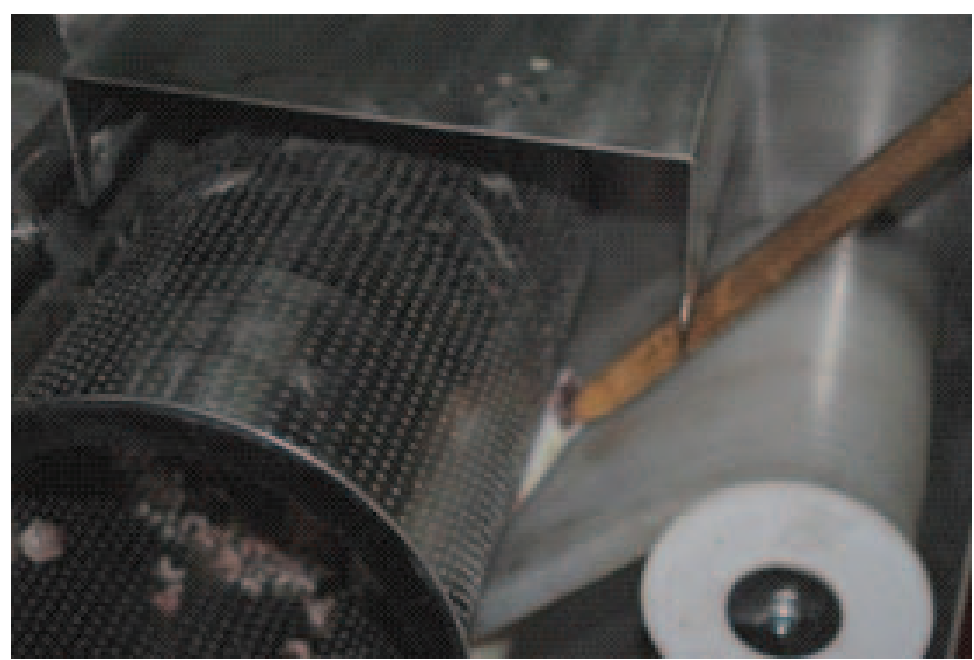

Gambar 3. Proses pemisahan tulang ikan kuniran Figure. 3. Deboning process of kuniran fish

lebih mudah diproses mengguna an meat-bone separator.

Preparasi ikan juga mempengaruhi rendemen daging lumat yang dihasilkan. Rendemen pada penelitian ini merupakan perbandingan bobot daging lumat terhadap bobot ikan awal yang telah dipreparasi. Pada ikan yang telah terbuka bagian dagingnya, yaitu yang telah disayat ataupun dibelah, lebih mudah untuk dipisahkan dagingnya menggunakan meat bone separator. Semakin terbuka bagian daging ikan yang akan diproses, semakin mudah pula proses pemisahannya. Selain itu, pada ikan yang dibelah, permukaan daging ikan yang bersinggungan dengan silinder penggiling semakin luas sehingga menghasilkan rendemen tertinggi, kemudian diikuti dengan ikan yang disayat dan kemudian ikan utuh (Tabel 1). Hal serupa juga didapatkan oleh Booman et al. (2010), bahwa faktor yang dapat meningkatkan rendemen dalam pemisahan daging menggunakan mesin antara lain ukuran, ketebalan, dan struktur ikan.

Secara umum daging ikan berwarna putih keabuan, kemerahan atau kekuningan tergantung pada jenis ikan maupun mutunya. Hemoglobin $(\mathrm{Hb})$ dan mioglobin (Mb) merupakan protein haem utama yang berpengaruh terhadap mutu daging ikan terutama dalam pembentukan warna dan kebusukan (Chaijan \& Undeland, 2015). Pigmen haem yang ditemukan di daging putih umumnya berasal dari $\mathrm{Hb}$ yang terkandung di dalam darah ikan (Johnston,1980), dan warna kemerahan pada daging ikan dapat menyebabkan menurunnya mutu daging lumat yang dihasilkan.

Pada penelitian ini, meskipun secara visual ikan yang dibelah memiliki warna yang lebih kemerahan, namun secara statistik, cara preparasi ikan tidak memberikan pengaruh signifikan pada warna daging lumat yang dihasilkan (Tabel 2 ).

\section{Preparasi Ikan terhadap Sifat Kimia Daging Lumat}

Kadar air daging lumat tertinggi didapatkan dari ikan yang dibelah $(80,93 \% \mathrm{WB})$, diikuti dengan preparasi ikan yang disayat $(80,10 \%)$ dan utuh $(79,37 \%)$. Hal tersebut disebabkan oleh air yang terikut

Tabel 1. Pengaruh preparasi ikan terhadap kecepatan pemisahan daging dan rendemen Table 1. Effect of fish preparations to separation process speed and yields

\begin{tabular}{clcc}
\hline No & $\begin{array}{c}\text { Jenis Preparasil } \\
\text { Preparations }\end{array}$ & $\begin{array}{c}\text { Kecepatan Proses Pemisahan(kg/jam)I } \\
\text { Deboning Speed (kg/h) }\end{array}$ & $\begin{array}{c}\text { Rendemen/ } \\
\text { Yields (\%) }\end{array}$ \\
\hline 1 & Utuh/Whole & 7.96 & 65.50 \\
2 & Disayat/Sliced & 11.35 & 67.50 \\
3 & Dibelah/Butterflied & 11.42 & 72.25 \\
\hline
\end{tabular}


ke dalam daging ikan saat proses preparasi dan pencucian. Pada ikan yang dibelah, permukaan daging yang terbuka menjadi lebih luas sehingga air yang terikut lebih banyak dibandingkan ikan utuh maupun ikan yang disayat. Sedangkan kadar abu tertinggi didapatkan pada daging lumat dari preparasi ikan utuh $(1,03 \%$ WB) dan kandungan terendah yaitu dari ikan yang disayat $(0,82 \%)$. Kadar abu pada daging lumat dapat menunjukkan banyaknya tulang ikan (kalsium) yang terikut pada proses pemisahan menggunaan meat bone separator. Semakin sedikit kadar abu yang didapatkan maka semakin baik mutu daging lumat yang dihasilkan (Tabel 3). Untuk kadar lemak dan protein, jumlah presentasenya lebih dipengaruhi oleh jumlah kadar air yang terdapat di daging lumat tersebut, dan juga faktor-faktor lainnya seperti denaturasi protein selama preparasi dan juga proses pencucian yang dapat menyebabkan turunnya kadar lemak dan protein.

\section{Preparasi Ikan terhadap Sifat Fungsional Fish Gel}

Pembentukan gel (gelation) merupakan sifat fungsional daging lumat ikan yang sangat penting, karena akan mempengaruhi mutu (reologi dan tekstur) olahan ikan yang dihasilkan. Pembentukan gel tersebut melibatkan proses denaturasi protein sebagian yang kemudian diikuti dengan irreversible aggregation hingga membentuk struktur jaringan tiga dimensi network (Lanier et al., 2004; Yin \& Park, 2014). Hasil uji tekstur terhadap daging lumat yang telah diolah menjadi fish gel, menunjukkan bahwa preparasi terhadap ikan mempengaruhi mutu fungsional dari produk yang dihasilkan, antara lain: hardness, gumminess, chewiness, springiness, dan cohesiveness (Gambar 3).

Secara keseluruhan, preparasi ikan dengan cara disayat memberikan tekstur fish gel terbaik, yaitu untuk karakteristik hardness (1295 g), gumminess (684), serta chewiness (576) dengan perbedaan nilai yang signifikan $(p<0,05)$. Sedangkan nilai terendah didapatkan dari ikan yang dibelah. Nilai springiness dan cohesiveness pada masing-masing perlakuan tidak menunjukkan perbedaan nyata $(p>0,05)$. Perlakuan ikan yang disayat memberikan hasil tekstur fish gel terbaik yang disebabkan oleh kecepatan yang lebih tinggi pada saat proses pemisahan daging ikan menggunakan meat bone separator dibandingkan ikan utuh, sehingga tingkat denaturasi protein juga semakin sedikit dibandingkan ikan utuh. Dibandingkan dengan ikan yang dibelah, kandungan partikel pengotor (impurities) seperti tulang yang terikut pada daging

Tabel 2. Warna daging lumat ikan

Table 2. Color measurements of minced fish

\begin{tabular}{lccc}
\hline \multicolumn{1}{c}{ Parameter/Parameters } & Utuh/Whole & Disayat/Sliced & $\begin{array}{c}\text { Dibelah/ } \\
\text { Butterflied }\end{array}$ \\
\hline Putih/Lightness & 53.6 & 54.1 & 54.2 \\
Merah/Redness & 6.1 & 6.0 & 6.7 \\
Kuning/Yellowness & 18.2 & 17.9 & 17.9 \\
\hline
\end{tabular}

Tabel 3. Kandungan kimia daging lumat kuniran

Table 3. Chemical composition of kuniran minced fish

\begin{tabular}{llccc}
\hline \multirow{2}{*}{ No. } & \multicolumn{2}{c}{ Parameter/Parameters } & \multicolumn{2}{c}{ Jenis Preparasi/Preparations } \\
\cline { 3 - 5 } & & Utuh/Whole & Disayat/Sliced & Dibelah/Butterflied \\
\hline 1. & Kadar air/Moisture content $(\% \mathrm{wb})$ & $79.37 \pm 0.06$ & $80.10 \pm 4.23$ & $80.90 \pm 0.72$ \\
2. & Kadar abu/Ash content $(\% \mathrm{wb})$ & $1.03 \pm 0.11$ & $0.82 \pm 0.11$ & $0.91 \pm 0.06$ \\
3. & Kadar lemak/Lipid $(\% \mathrm{wb})$ & $0.88 \pm 0.18$ & $0.69 \pm 0.01$ & $0.73 \pm 0.01$ \\
4. & Kadar protein/Protein $(\% \mathrm{wb})$ & $18.71 \pm 0.88$ & $18.38 \pm 0.90$ & $17.45 \pm 0.16$ \\
\hline
\end{tabular}



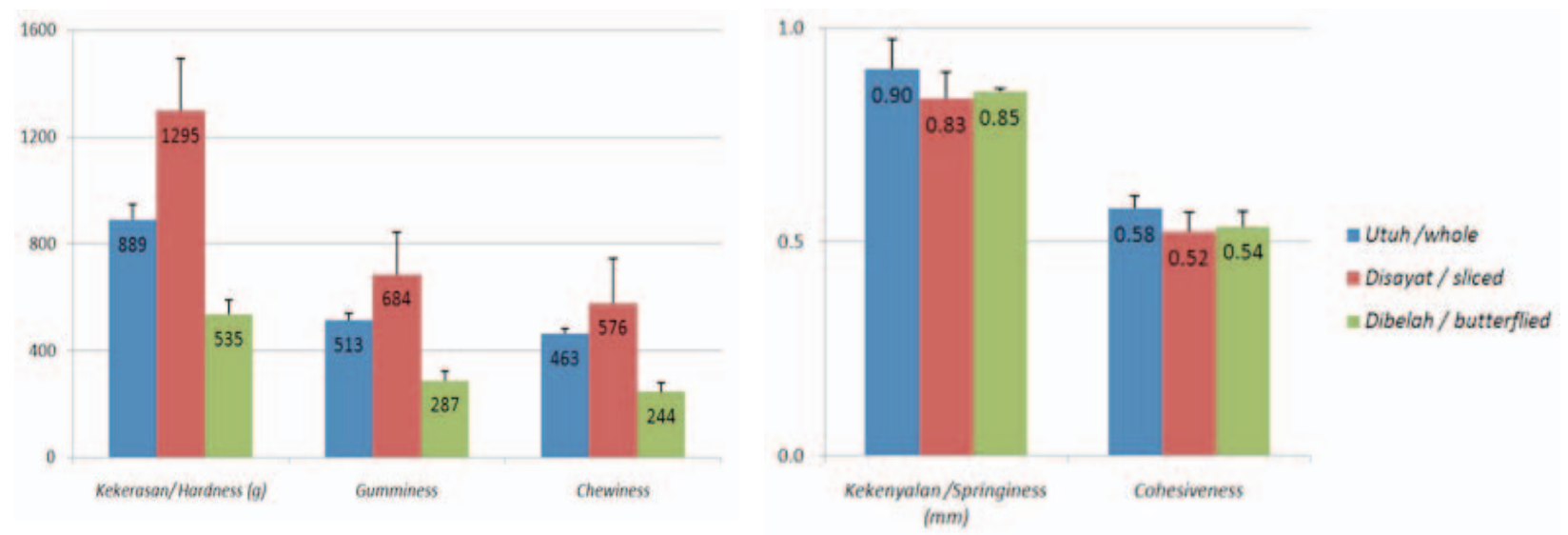

Gambar 3. Jenis preparasi ikan terhadap tekstur fish gel.

Figure 3. Types of preparation on fish gel texture.

lumat ikan yang disayat relatif lebih sedikit, sehingga turut mempengaruhi kualitas fish gel yang dihasilkan.

Karakteristik fish gel tersebut menunjukkan nilai mutu daging lumat yang dihasilkan, yang dipengaruhi oleh kandungan protein miofibril, dan juga kondisi pengolahannya (Mateos \& Montero, 2002). Menurunnya mutu daging lumat untuk ikan yang dibelah, diduga karena terjadinya denaturasi protein miofibril saat proses preparasi maupun saat pemisahan daging meggunakan meat bone separator. Denaturasi dini protein ikan selama pelumatan daging ikan akan mempengaruhi tekstur yang dihasilkan, dan dapat dideteksi secara sensoris oleh panelis (Shaviklo et al., 2010).

\section{KESIMPULAN}

Cara preparasi ikan sebelum dipisahkan dagingnya menggunakan mesin meat bone separator menyebabkan berubahnya nilai kekerasan dan struktur fisik ikan, sehingga mempengaruhi lama waktu proses pemisahan daging, rendemen, serta mutu daging lumat yang dihasilkan. Secara umum, teknik preparasi dengan cara disayat, menunjukkan hasil terbaik dengan nilai rendemen yang tinggi $(67,50 \%)$, waktu proses pemisahan yang lebih cepat $(11,35 \mathrm{~kg} / \mathrm{jam})$, serta kadar abu terendah $(0,82 \%)$, dibandingkan dengan preparasi ikan utuh, dan dibelah. Selain itu, pada preparasi ikan dengan cara disayat juga memberikan sifat tekstur fish gel terbaik (hardness 1295 g, gummines 684 g, chewiness 576 g).

\section{DAFTAR PUSTAKA}

AOAC. (2000). Official Methods of Analysis of AOAC International, 17th ed. AOAC International, Md., USA.
Booman, A., Marquez, A., Parin, M.A. \& Zugarramurdi, A. (2010). Design and testing of a fish bone separator machine. Journal of Food Engineering, 100, 474479.

Chaijan, M. \& Undelan, I. (2015). Development of a new method for determination of total haem protein in fish muscle. Food Chemistry. 173, 1133-1141.

Johnston, I.A. 1980. Specialisations of fish muscles. In Goldspink, D.F. (ed.). Development and Specialisation of Skeletal Muscle (pp. 123-148). Cambridge: Cambridge University Press.

Kim, B.Y. \& Park, J.W. (2000). Rheology and texture properties of surimi gels. In Park, J.W (ed.). Surimi and Surimi seafoods (pp. 267-324). Marcel Dekker, Inc. Astoria, Oregon.

Lanier, T.C., Carvajal, P., \& Yongsawatdigul, J. (2004). Surimi gelation chemistry. In Park, J.W. (ed.). Surimi and surimi seafood (pp. 451-470). Marcel Dekker, New York. 2nd ed.

Mateos, M.P. \& Montero, P. (2002). Effects of cations on the gelling characteristics of fish mince with added anionic and ionic gums. Food Hydrocolloids, 16, 363373.

Mendelsohn, J.M. \& Callan, J.G. (1980). Evaluation of a prototype fish cleaning machine with proposals for a commercial processing line. Marine Fisheries Review.

Newman, P.B. (1981). The separation of meat from bone: a review of the mechanics and the problems. Meat Sci., 5(3), 171-200.

Purbayanto, A., Santoso, J., Riyanto, R., Purnomo, A., Pramono, B. \& Susanto, A. (2009). Prosiding seminar nasional teori dan aplikasi teknologi kelautan.

Sedayu, B.B., Erawan, I.M.S. \& Utomo, B.S.B. (2013). Rancang bangun dan ujicoba mesin pemisah daging ikan berdaya listrik rendah. Jurnal Pascapanen dan Bioteknologi Perikanan, 8(2), 125-132.

Shaviklo, G. R., Arason, S., Thorkelsson, G., Sveinsdottir, K., \& Martinsdottir, M. (2010). Sensory attributes of haddock balls affected by added fish protein isolate and frozen storage. Journal of Sensory Studies, 3, 316-331. 
Szczesniak, A., Brandt, M.A. \& Friedman, H.H. (1963). Development of standard rating scales for mechanical parameters of texture and correlation between the objective and the sensory methods of texture evaluation. Journal of Food Science, 29, 397403.

Yin, T. \& Park, J.W. (2014). Effects of nano-scaled fish bone on the gelation properties of Alaska pollocksurimi. Food Chemistry, 150, 463-468. 
